\title{
Evocative allusions in Matthew: Matthew 5:5 as a test case
}

\author{
Robert L Brawley ${ }^{1}$ \\ McCormick Theological Seminary (Chicago, USA) \\ Research Associate: University of Pretoria
}

\begin{abstract}
Combining theories of intertextuality and abductive reasoning, this article demonstrates the figurative nature of scriptural allusions in Matthew. Allusions form figurations that open new perspectives for readers inasmuch as the source text and the new text stand in a tensive relationship in which each modifies the other and in which together they evoke meaning beyond the mere sum of the two independent texts. Allusions also form figurations inasmuch as arguments that are analogous to logic. Surprising, original, uncanny correlations between the source text and the new text involve what Charles Peirce called abductive reasoning which also challenges constructs of reality. This article interprets Matthew 5:5 as an allusion to the Abrahamic promise of the inheritance of the land and the blessing of all the families of the earth mediated through Psalm 36 ( $L X X)$ and describes the figurative nature of the allusion using Harold Bloom's revisionary ratios. Another version of the article will also be published in Kim, $P$ \& Ringe, $S$ (eds), Literary encounters with the reign of God: Essays in honor of Robert $\mathbf{C}$ Tannehill, Harrisburg, PA: Trinity Press International (Forthcoming).
\end{abstract}

\section{INTRODUCTION}

When coach Mike Davis's Indiana University team beat the University of Oklahoma in a semi-final game of the National Collegiate Athletic Association's basketball tournament in 2002, an Indiana fan held up a sign: "Davis and

\footnotetext{
${ }^{1}$ Prof Dr Robert L Brawley is the Albert G McGaw Professor of New Testament at the McCormick Theological Seminary in Chicago (IL), USA. This study is based upon a paper read to the Gospel of Matthew Seminar, Studiorum Novi Testamenti Societas, $57^{\text {th }}$ General Meeting, University of Durham, United Kingdom, 31 July-4 August 2002. Prof Dr Robert L Brawley participates as research associate in the research project "Biblical Theology and Hermeneutics", directed by Prof Dr Andries G van Aarde, Department of New Testament Studies, Faculty of Theology, University of Pretoria.
} 
Goliath." The poster evokes the biblical account of David and Goliath, which is absent. But to what degree does the placard resonate with the story? To what degree does it ignore or reject details of the story, and to what degree does it cast them in new light? The Philistine Goliath curses David by his gods (1 Sm 17:43), whereas David comes in the name of YHWH Sabbaoth (17:45). "Davis and Goliath" abandons the ethnic war and theology of the story of David and Goliath only to reiterate them in terms of cultural loyalties. An athletic contest supersedes war. But do questions of theological allegiance remain on the screen given that players and fans at times assumed postures of prayer, and after Indiana player Tom Coverdale injured his ankle, one supporter sent some water blessed by the Pope to help heal the injury? In sum, "Davis and Goliath" teases the mind beyond a simplistic, defined correlation.

In another case, Clifton Black (2001:144) critiques devotion to method in biblical studies and drops the line "Dr Strangeuse: Or, How I Learned to Stop Enjoying and Love the Skill." Black alludes to a classic movie title that is absent: "Dr Strangelove, Or: How I Learned to Stop Worrying and Love the Bomb." Were it not for TV re-runs of this satire on the cold-war, Black's allusion might sail over his readers' heads. The movie depicts a conflagration instigated when a U S airplane drops a nuclear bomb on the Soviet Union. When the bomb doors open, the berserk commander of the flight crew rides the bomb as if he were a cowboy on a bronco.

To what degree does Black's play on the title cast the values of the movie in new light? Am I going down the wrong road when I juxtapose Black's line with the film's title, and then suppose that (1) the setting of competitive methods in biblical studies is as ludicrous as the cold-war in the movie, (2) fascination with method is a matter of misdirected affection - strange love indeed - and (3) dogmatic devotion to method in biblical studies is crazy? ${ }^{2}$ Anticipating a later discussion, I point out that Black's title forms a figuration (trope) on a movie that as satire is already figurative.

\footnotetext{
${ }^{2}$ In a telephone conversation, Black confirmed only my second conclusion as fitting his authorial intent. But he found my interpretations plausible and suggested that authorial activity both constrains and opens up interpretive possibilities. Unconscious aspects of writing can enable interpreters to uncover dimensions that escape authorial intent (see Finkelpearl 2001:79-81).
} 
In another case Black (2001:149) writes about preaching: "God's parabolic wisdom will unfailingly prosper - perhaps never more evidently so than when revealed to prophets whose persuasiveness irritates the life out of them, whose most memorable performance is a beachhead in fish-vomit." Black again evokes a text that is absent - the story of Jonah whose resistance to his prophetic task results in his dire distress in the belly of a fish, but whose prayer for deliverance results in an act of God in which the fish vomits Jonah onto dry land. When Jonah preaches to the Ninevites, their situation replicates his distress in the belly of the fish. Like Jonah, they cry to God. God delivers the Ninevites from their distress just as God delivered Jonah. Prophetic preaching in Nineveh prospers. That is not all. Upon his success, Jonah reveals that the motivation of his initial reluctance is eminently but perversely theocentric. He knows that God is merciful - a central confession of Israel: "For I knew that you are a gracious God and merciful, slow to anger, and abounding in steadfast love, and ready to relent from punishing" (Jonah 4:2). But in ethnic jealousy, he does not want God to show mercy upon the Ninevites. He would rather see his prophecy of divine destruction fulfilled. Thus, Black's sentence points to divine accomplishments that reach their goal through prophetic agents in spite of motivations that may be at crosspurposes with God. Again Black plays figuratively on a text that as parable is already figurative. Intertextuality

In spite of advances in theories of intertextuality, investigations of Matthew's use of scripture continue to perpetuate methods of determining sources and models that influence Matthew's composition. In a volume whose dust cover promotes "an up-to-date picture of the most recent research," Maarten Menken searches conventionally for sources of Matthew's use of scripture in the massacre of the innocents (Menken 2000:106-125). ${ }^{3}$ Intertextuality has also been construed as mimesis, not in the sense of the representation of reality (E Auerbach) but in the sense of Greek school exercises in which students write compositions that imitate classical authors. The premise of this approach is that Matthew duplicated scriptural models as an aspect of composition. Thomas

\footnotetext{
${ }^{3}$ In spite of his linguistic astuteness, because intertextuality includes tensive relationships between texts, Maarten Menken's (2000) reliance on tension between the citation and the Matthean context lacks theoretical sophistication.
} 
Brodie (2000; cf 1992:697-718) has produced a number of studies that draw especially on Elijah and Elisha cycles as literary models.

Martin Rese's (1969) study on the use of scripture in Luke-Acts initiated a shift beyond identification of sources and compositional devices. He proposed a hermeneutical function in which scripture provides a lens through which the New Testament attempts to make sense of the Christ event. Reciprocally, the Christ event provides a lens through which to understand scripture. This suggests a key for interpreting citation formulas that introduce no citations. For example, Mt 26:54 asks, "How therefore will the scriptures be fulfilled that it is necessary to happen thus?" without citing a single text. This implies (1) that scripture as a whole provides a framework for understanding the Christ event, and (2) that there are patterns in scripture, such as people who suffer for fidelity to God, that help readers of the Gospel understand the Christ event.

In 1996 at the Colloquium Biblicum at the University of Leuven, Belgium, Donald Senior (1997:89-115) presented a study of Matthew's use of the Old Testament in the passion narrative. He rehearsed the conventional question of sources but also categorized the functions of quotations and allusions as (1) providing an aura of biblical authority, (2) conferring a new understanding on God's voice in scripture (similar to Rese's hermeneutical function), (3) serving as the structure for Matthean composition (mimesis), and (4) making a fundamental affirmation of the fulfillment of God's plans and promises. Only the second category moves beyond the conventional attempts to determine sources and models for composition. Emerson Powery (1999:113-251) produced a similar study but with emphasis on the function of formula citations in the narrative. In particular he made a distinction between the citation practices of the narrator and of Jesus as a character in the narrative. His narrative functions, however, are conventional - defending, predicting, instructing , correcting.

For Julia Kristeva (1980:36-63) intertextuality has little to do with sources or models of composition. It has to do rather with how texts affect society and culture according to the way they make utterances (1) by incorporating textual systems (anonymous cultural conventions that are larger than any one text) or (2) 
by referring to textual patterns that they do not themselves contain. In Mt 26:54 Jesus refers to a textual system that Matthew does not contain: "How therefore will the scriptures be fulfilled that it is necessary to happen thus?" "The scriptures" are a textual system that Matthew cannot and does not contain. The incorporation of or reference to textual systems produces a shift in values, and Kristeva focuses on the shift in value within the new text. The issue for her is the transformation of the function of the textual pattern or reference.

If I write my own thoughts, my thinking is different from my writing with a corresponding distinction in values. But to claim to write my own thoughts implies that the two activities of thinking and writing are equivalent with the result that the implied equivalence must be figurative. In a related way, Mt 26:54 implies equivalence between the arrest of Jesus and scriptures whereas the scriptures are chronologically independent from the arrest of Jesus. Matthew's claim thus recasts diachrony into synchrony, a move that Harold Bloom (1975:112; 1982) calls "a lie against time" (cf Kristeva 1980:65). Matthew's text makes two distinct discourses equivalent and "admits the existence of an other (discourse) only to the extent that it makes it its own" (Kristeva 1980:46; emphasis original). Fulfillment is, therefore, figurative. This is to say that incorporating textual patterns or referring to them in a new writing inevitably forms a figure of speech, a trope, in which differences parade as coherent. The troping confers a new voice on textual patterns that are incorporated or references elicited from outside the new text at the same time that the incorporation or references still speak with voices they already possess (Kristeva 1980:73; in dependence upon Bakhtin). The interplay between old and new texts reconfigures the social construction of reality against the culture of both texts (see Finkelpearl 2001:82). This figurative aspect of intertextuality has largely gone unnoticed in interpretations of Matthew's use of scripture as source criticism or literary imitation.

Kristeva advocates intertextuality on a large scale far beyond the relationship of recognizable textual patterns with each other. To illustrate, Kristeva argues that Western society recognizes differences between males and females but then fallaciously takes the differences to mean that one gender ranks above the other. She then argues that social constructs that rank males over females 
find expression in literature as the heroic idealization of woman (Kristeva 1980:49-50). Kristeva's interests lie, therefore, in large issues of value involved in the move from conventional utterances that males and females are different to a textual expression (the idealization of woman) that produces a shift in values (from nonhierarchical difference to patriarchy).

Though Kristeva reflects on citations, she allows little place for analysis of citations and allusions as intertexts (see Culler 1981:106). This, however, is precisely the interest of many interpreters of Matthew. Daniel Boyarin (1990:135 note 2) has helped to define a level of intertextuality that is both distinct from and in continuity with Kristeva. He distinguishes between influences on composition as a diachronic approach and mutual relationships between definable texts as a synchronic approach. The diachronic approach means that texts are viewed in relationship with each other in temporal sequence. The synchronic approach means that two texts are viewed in a mutual relationship with each other beyond their temporal sequence. The purely diachronic approach is distinguished from intertextuality whereas the synchronic relationship between definable texts is intertextuality.

A comparison of the Masoretic Text of Hosea 11:1 ("oupout of Egypt I [God] called my [God's] son [singular]") with

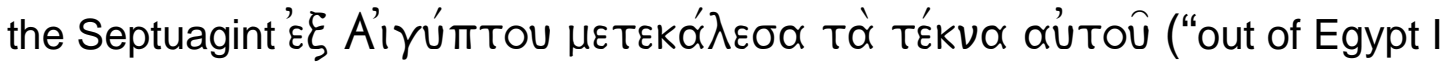

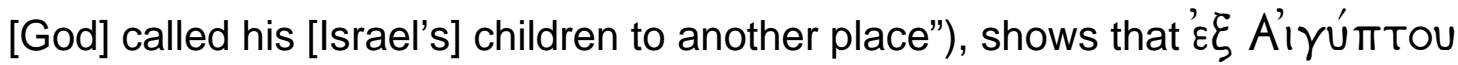

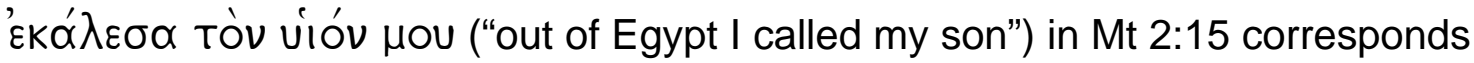
to the MT and not to the LXX. ${ }^{4}$ This is clearly a diachronic issue of comparing Matthew's text with possible sources. When, however, readers recognize a mutual relationship between a citation or allusion and a precursor that involves a shift in values, this is a synchronic issue of how the precursor and successor play back and forth on one another. Conventionally, Mt 2:15 is understood as a proof text that violates the context of Hos 11:1. But readers who know Hos 11:1 in its

\footnotetext{
${ }^{4}$ The appearance of "my son" (singular) in the Greek versions of Aquila, Symmachus, and Theodotion complicate the issue of source (see Gundry 1967:93-94).
} 
context can play Matthew's citation off against it, identify Jesus as God's son, add the slaughter of the innocents to the parallels in plot that are already apparent (Mt 2:16-18), and construe Jesus as recapitulating Israel's exodus from Egypt. Significantly, the movement in Matthew immediately after the citation is not from Egypt, as Hosea anticipates, but to Egypt (Powery 1999:125; Gundry 1967:93-94,195; see Smith 1972:47), a reiteration of Jacob's - that is, Israel's sojourn in Egypt.

This kind of synchrony entails a diachronic element in that it presupposes a temporal relationship between a source text and a new text. The diachrony may involve, in fact, at least one more step. Matthew may appropriate scripture indirectly through interpretive traditions. To anticipate, I will suggest that God's promise to Abraham to give his descendants "this land" (Gn 12:7) is mediated to Matthew by interpretive traditions in Judaism.

A silver symbol on the back of my neighbor's car provides another kind of example of intertextuality. Until one gets very close it appears to be a simple design of a fish with some lettering in between two arcs that outline the body and tail. Up close, however, one sees that the body has feet, and the lettering inside the twin arcs is "DARWIN." This symbol makes reference to another textual system that is absent. Many Christians in the United States have silver symbols of a fish on the backs of their cars with the lettering IX $\Theta Y \Sigma$ (a Greek acronym for "Jesus Christ, Son of God, Savior") or "JESUS" in between the arcs. The shape of the symbol on my neighbor's car contains the textual pattern of the Christian symbol. My neighbor's symbol trumps the Christian symbol. It takes it over and contains it by inference, but only on its terms. The value inverts an identification with faith to a challenge to faith presumably in the name of science. Nevertheless, the Christian symbol stands in a dialectical interplay with the Darwinian one, and someone with a Christian perspective can take the Christian symbol as the trump.

The mutual relationship between texts under the synchronic approach possesses the quality of a trope. Much of what parades as intertextuality in biblical study misses this troping. The traditional diachronic approach subjects 
Matthew's appropriation of scripture to evaluation as to whether the citation or allusion (1) respects the context of the precursor, (2) is lifted out of its context, or (3) contradicts its context (Mead 1963-64:279-289; Fitzmyer 1960-61:305-350). Such an approach envisions the relationship between the source text and the new text as essentially static. But intertextuality accents a dynamic dialectic between the precursor and the successor in which each stands in degrees of both conflict and consonance with the other. The language is therefore tensive, a quality of language that Robert Tannehill (1975:11-14, 52-55) underscored in The sword of his mouth. Confronted with allusions and citations, readers may constantly shift perspective to see the successor from the point of view of the precursor or the precursor from the successor - does DARWIN trump IX $\Theta Y \Sigma$, or does IX $\Theta Y \Sigma$ trump DARWIN? Or for someone who has integrated science and religion, does the attempted trump in either direction become irrelevant? From the perspective of the precursor text, the new text may advance perception beyond the limits of the precursor. From the perspective of the new text, the precursor may activate meaning beyond the limits of the new text. Finally, readers who view the juxtaposition of intertexts holistically may perceive them together as one figuration that extends meaning beyond the mere sum of the two independent texts (Brawley 1995:8-10).

The tensive interplay among texts is figurative as in the case of metaphors, and as in the case of metaphors it enables readers to envision reality in a new way. Harold Bloom has associated the dialectical relationships between precursor and successor texts with standard figures of speech: irony, synecdoche (a part for the whole or whole for part), metonymy (a name used for something with which it is associated), hyperbole, metaphor, and metalepsis (a trope of a trope). ${ }^{5}$ Bloom separates these figurations analytically, but they may function simultaneously. To give a case in point, the appropriation of Hos 11:1 in Mt 2:15, "Out of Egypt I called my son," is ironic in that two levels of understanding are going on at the same time, one level with respect to Israel in Hosea

\footnotetext{
${ }^{5}$ Bloom repeats his analysis in a number of works, e g, The anxiety of influence: A theory of poetry (1973:14-16).
} 
11:1 and a second level where Jesus recapitulates Israel's exodus. Interpreters who take Matthew's use of Hos 11:1 as a proof text are duped by the irony, because they understand it on one level only. Further, the calling of God's son out of Egypt is a synecdoche for the entire exodus. To imply that Jesus recapitulates Israel is hyperbole, that is, the text rises to a new level of meaning that represents a gain over the precursor alone. The play on "son" in Hosea is metonymic. That is, the name "son" denotes a people with whom the name is associated, namely, the children of Israel. Finally, Matthew's use of the text is metaleptic, because it makes a figuration on a text that already tropes Israel's relationship with God under the figure of a father caring for his infant.

\section{ENTHYMEME: RHETORIC OF LOGIC}

Consideration of enthymemic rhetoric also presses upon us the metaphorical character of biblical citations and allusions. To examine enthymemic rhetoric is to attempt to follow the logic of arguments that replicate aspects of formal syllogisms, though only approximately. This approximation indeed provokes some purists to set formal logic over against rhetoric, that is, rhetoric allegedly persuades by reasoning that is effective but defective; logic allegedly demonstrates by proof (so Aristotle, Rhetoric 1354a; 1355a; see Hellholm 1995:127129). ${ }^{6}$

Charles Peirce (1957:236-237) called an inferential step in forming a hypothesis or generating any new concept an "abduction." Though it is related to experience, that is, to a worldview, such an inference has no grounding in previous knowledge and is therefore a kind of conjecture (see Reilly 1970:30-31, 37; Lanigan 1995:49-52; Ochs 1968:60, 114-120; Fann 1970:17-18). An example is the fresh metaphor in Job 38:8: "... when the sea burst forth from the womb." The conventional side of the metaphor is the gushing of amniotic waters from a mother's womb at birth. The creative side is the association of erupting seas with amniotic waters.

\footnotetext{
${ }^{6}$ Richard Lanigan (1995:52) shifts the discussion from the logic of rhetoric to the rhetoric of logic, that is, the rhetoric of syllogistic-like enthymemes.
} 
Peirce valued the element of surprise in motivating the development of thought. The surprise can be either disappointment or anticipation (Reilly 1970:25). Disappointment disrupts the ordinary ("All flesh is grass"); anticipation creates expectation beyond it ("If God so clothes the grass, will God not also clothe you"). But the surprise is also a new thought in that it correlates elements that heretofore were never associated, as in the correlation of the seas with amniotic waters in Job 38:8. Though the conceptual elements pre-exist in a world view, they have never been related to each other beforehand. Abduction is, therefore, astute original thinking.

Syllogisms involve three assertions, conventionally called major premise, minor premise, and conclusion. Peirce referred to these as "rule," "case," and "result." Deductive reasoning follows the pattern rule + case $=$ result. Rule: All the beans from this bag are white. Case: These beans are from this bag. Result: These beans are white. Inductive reasoning inverts the minor and major premises following the pattern case + result $=$ rule. Case: These beans are from this bag. Result: These beans are white. Rule: All the beans from this bag are white. (This is effective reasoning if an investigator draws the beans from the bag one at a time or in handfuls, and the beans are always white.) By contrast, abductive reasoning ends with a case that derives from a known rule and result following the pattern rule + result $=$ case, that is, the abduction is an explanation of a surprising event (result) by reasoning that it is a special case of a general rule. Rule: All the beans from this bag are white. Result: These beans are white. Case: These beans are from this bag (Fann 1970:20-21). An abduction is an assertion that a phenomenon belongs to a known class with which it has previously not been associated. More elaborately, the result is an assertion that a particular thing possesses similarity to the general class, and hence, belongs to the class. The recognition of similarity between the class (rule) and the particular (result) leads to a discovery (case) that asserts similarity (1) with the rule and similarity (2) with a result that the case anticipates (Lanigan 1995:50; Reilly 1970:32-33, 61; Fann 1970:10, 21; Bateson \& Bateson 1987:174-175). To illustrate, Sir Isaac Newton drew an abductive relationship between his proverbial apple falling to the ground and the force that determines the movement of 
heavenly bodies in relation to one another. A falling apple is a case that exhibits a relationship with gravity, which is the rule, and a relationship with predictable motion between bodies, which is the result that the falling apple anticipates.

Rhetorical enthymemes differ from syllogisms in two respects. First, enthymemes typically leave at least one of the three assertions (rule, result, case) unexpressed. Part of the rhetorical effect is to evoke unexpressed assertions from readers. Not all enthymemes employ abductive reasoning. In fact they can follow rather conventional deductive or inductive patterns. When some Pharisees ask Jesus about divorce in Mt 19:3, the interlocutors share with Jesus a conventional unstated rule, namely, that proper interpretation of scripture provides the answer. But what is true of enthymemes in general is also true of enthymemes that involve abductive reasoning. Because such enthymemes leave some assertions unexpressed, they will appear not to have the complete form of a syllogism. In this sense abductive enthymemes are "formally defective." A second distinction between syllogisms and enthymemes is that some unstated assertions may be cultural presuppositions that do not qualify as premises in formal syllogisms. Moreover, abduction is a leap of invention that enables readers to grasp a reality that is not yet proved or disproved by inductive or deductive reasoning. In these senses abductive enthymemes are "materially defective." ${ }^{7}$ In the case concerning divorce, Jesus' interlocutors reason deductively following the pattern rule + case $=$ result. Rule: Interpretation of scripture is determinative for divorce. For the case, Jesus' interlocutors cite the only text in their scriptures that deals with the process of divorce, Dt 24:1. This is to say, they cite a conventional text: Moses commands giving a wife a certificate of divorce. Result: Divorce is permissible (unexpressed). Jesus, however, associates Genesis 2 abductively with divorce. He makes a non-conventional new association of Genesis 2 with the known class of texts pertaining to divorce. The shock of the new association evokes new ways of looking at divorce according to the pattern rule + result $=$ case. Rule: God made male and female. Result: God joins the two. Case: separation is not permitted. Because this is an

\footnotetext{
${ }^{7}$ Aristotle (Rhetoric 2.1402a) speaks of enthymemes that are not absolute but probable in particular cases (see Lanigan 1995:52-55; Hellholm 1995:121, 127-28, 131; Kennedy 1984:7, 1617, 49-51; Fann 1970:58-59).
} 
abduction, it has the nature of a hypothesis that is subject to attempts to verify or disconfirm it (Peirce 1957:34-35, 44-51; Hellholm 1995:132). A historical critical analysis, for example, could claim that in its literary and historical contexts, Genesis 2 has to do with an explanation of the origin of marriage rather than with its dissolution.

Jesus' abduction about God's intention in the creation of human beings then becomes a rule for two deductive enthymemes (rule + case $=$ result). Rule: God joins male and female as God's original intention. Moses' allowance for divorce is, therefore, not the rule as the interlocutors presume, but the case. The result is hardness of heart against God's intention in creation. The other enthymeme is grounded in the same rule: God joins male and female as an original intention. The case is divorce and remarriage, and the result is adultery.

The rhetorical enthymeme is the metaphorical twin of the logical syllogism. Isaiah 40:6-8 illustrates the metaphorical nature of rhetorical enthymemes: "All flesh is grass and all human splendor as a blossom on grass. The grass withers and the blossom falls off. But the word of our God endures forever." Behind the assertion lies a syllogistic-like argument: Grass dies, humans die, humans are grass (Bateson \& Bateson 1987:26).

Challenging constructs of reality through the imaginative association of elements heretofore unrelated is tropological. Abduction functions like a fresh metaphor, which also associates something novel with something conventional in order to transform conventional perspectives. Thus, abductive argument begins with shock, a challenge, disorientation. The shock breaks the frames of conventional thinking and confronts readers with a new way to construe reality.

\section{3. "BLESSED ARE THE MEEK"}

My proposal is that Jesus' third beatitude in Matthew is marked by both allusive intertextuality and abductive reasoning. Allusions are highly dependent upon cultural currency, as Black's coinage of Dr Strangeuse is dependent upon the cultural currency of "Dr Strangelove." ${ }^{8}$ For the blessedness of the meek who will

\footnotetext{
${ }^{8}$ In fact when I presented an earlier form of this paper to a seminar with international participants, a number of them acknowledged that they did not recognize the movie title.
} 
inherit the earth I suggest a cultural repertoire that does not readily meet the eye, namely, God's promises to Abraham. The beatitude picks up two prominent themes of the Abrahamic covenant: (1) the blessing in him of all the people of the earth (Gn 12:3) and (2) God's gift of the inheritance of land to his descendants ("seed") (Gn 12:7; 13:14-15) (Grundmann 1968:126). ${ }^{9}$ I indicated earlier that interpretive traditions in Judaism mediate the Abrahamic covenant to Matthew. A part of this tradition is Ps 36:11 LXX (Ps 37 in English versions), with which Mt 5:5 shares a high degree of verbatim agreement. Though Matthew's version contains the textual pattern of Ps 36:11 LXX, ${ }^{10}$ Matthew does not merely take it

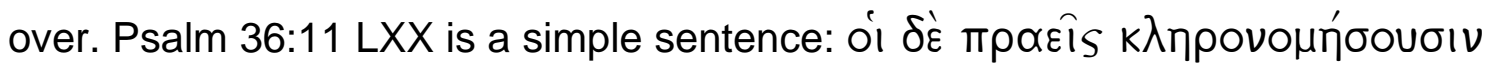
("the meek will inherit land"). Mt 5:5 is a complex sentence that identifies those who are blessed in the first part and gives the ground for the blessing in a dependent clause. Matthew also uses the definite article before "land": $\mu \alpha k \alpha ́$ pı ı

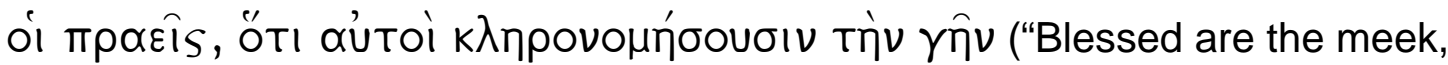
because they will inherit the land").

As I indicated earlier, cultural presumptions can serve as unexpressed assertions in enthymemic rhetoric. One such presumption is Abrahamic traditions. It is impossible to trace the development of Abrahamic covenant traditions precisely, but some mileposts along the way are clear. For its part, Ps 36:11 LXX represents a development of the Hebrew version of Ps 37:11. Though the verb רשש can connote "inherit," its nuance is preferably "to take possession." The much more common Hebrew terms for inheriting are the verb נחל and its

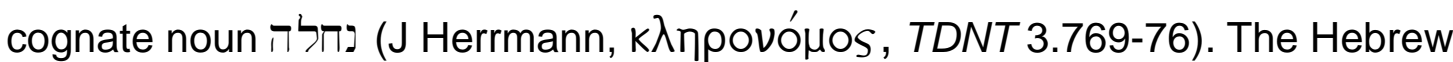
implicates possession of land; $k \lambda \eta \rho \circ{ }^{\prime} \mu \mu \varepsilon^{\prime} \omega$ in Ps 36:9, 11 LXX accents

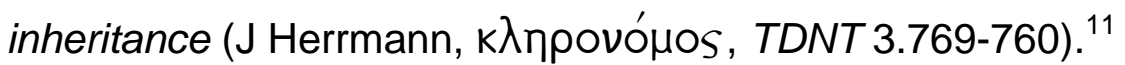

\footnotetext{
${ }^{9} \mathrm{H}$ Frankemölle (1994:211) associates the promise of the land with the declaration that Jesus' listeners are the salt of the earth $(5: 13)$.

${ }^{10} \mathrm{H}$ Betz (1995:125) takes Mt 5:5 as an "adaptation" of Ps 36:11 LXX (see Guelich 1982:101; LuZ 1989:236; Broer 1986:80).

${ }^{11}$ Ps 36:11 lacks the eschatological perspective of Matthew (see Dupont 1969-73:3.482).
} 
Further developments of Abrahamic covenant traditions are evident in a broad cultural repertoire. Matthew customarily cites or alludes to scripture rather than literature of the Second Temple period, but references and allusions are likely mediated through Second Temple traditions. Debates about who qualified as a descendant of Abraham are a part of these traditions. At one extreme, ethnic exclusivism disqualified anyone who was not of Abrahamic lineage. At the other, a spiritualized universality admitted all who followed in the footsteps of Abraham (Paul's view in Rm 4:12). Jubilees 22:16-18, 4 Macc 6:17-22, PssSol 9:9-11, and the Dasmacus Document (CD 12.11) express an ethnic priority for Abraham's descendants over the Gentiles. But 1 Enoch 90:33 takes Abraham allegorically to be the ancestor of all humanity as if he were like Adam. Josephus (Ant 1.220-41; 12.225-26) also suggests that Abraham was a universal ancestor by deriving Jews from Sarah and Gentiles from Hagar and Keturah. ${ }^{12}$

One trajectory of Jewish tradition made a startling development in the identification of the land that God promised to the descendants of Abraham. In Gen 13:14-15 God promises to give Abraham and his offspring all the land that he can see to the north, south, east, and west. What is this land? It so happens that both the Hebrew אר grow), (2) land (territory or country), or (3) earth (the entire planet). The Abrahamic covenant is so charged with interpretive potential that one trajectory of Jewish tradition took the promise of $\mathrm{Gn} 13: 14-15$ to mean the entire earth. The specific promise of the land of Canaan (17:8) need not conflict with the promise of the entire earth beyond the inheritance of Canaan. So the tradition pushed the promise into an eschatological future and made it universal - the whole earth. ${ }^{13}$

\footnotetext{
${ }^{12}$ In dependence upon Polyhistor and his sources, Eusebius (Praepar Evang 9.20; 9:29.1-3) traces the Assyrians, Africans, the people of Carthage, and Moses' wife Zipporah from Keturah. 1 Macc 12:21 claims that the Spartans are descended from Abraham.

${ }^{13}$ The understanding of the Abrahamic promise as the whole earth appears in Sir 44:19-21; Jub 17:3; 19:21; 22:14; 32:18-19; Rm 4:13; 1 Cor 6:2; Heb 2:5. According to Sifre on Dt 34:1-4, when Moses looked into the promised land on Mt Nebo, God showed him the whole earth (see Philo, Vit Moses 1.155; Mek Ex 14:31; Dupont 1969-73:3.475-86). By missing the allusion to the Abrahamic covenant, Betz (1995:128) takes $\dot{\eta} \gamma \hat{\eta}$ to mean the whole earth as the place of mission, as in Mt 28:18-20.
} 
Matthew's third beatitude is more than likely heir to Abrahamic covenant traditions as mediated through Jewish tradition. It asserts the blessedness of the Abrahamic promise, though the term it uses for "blessed" ( $\mu$ akópios) is not the characteristic vocabulary that the Septuagint employs in relation to the Abrahamic covenant ( $\varepsilon \dot{u} \lambda \circ \gamma \varepsilon \dot{\varepsilon} \omega)$. On the other hand, Ps 32:12 LXX uses

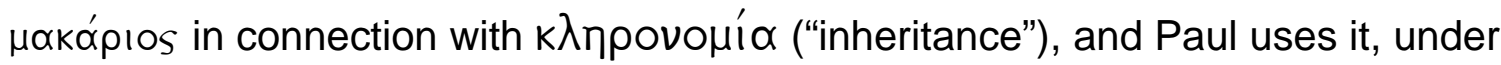
the influence of Ps 31:1-2 LXX, precisely in relation to the Abrahamic blessing in Rom 4:6-9. An additional reason to infer an intertextual allusion is a widely recognized relationship with Isa 61:1-2 in the immediately preceding beatitude of

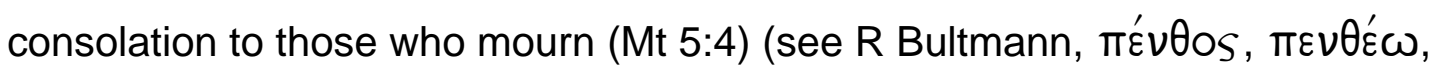
TDNT 6.43; Frankemölle 1971:59). ${ }^{14}$ Matthew's third beatitude, therefore, makes reference to a textual system regarding Abrahamic traditions that it does not contain and with which it is in intertextual interplay.

Hans Dieter Betz raises the question of whether the predicates in the beatitudes that describe those who are blessed, such as "poor in spirit," are literal or metaphorical and decides for the metaphorical. The poor in spirit are those who understand the human condition as poverty in contrast to arrogance. He takes "the meek" to be a variation on "the poor in spirit" (Mt 5:3). The same reasoning supports taking the second half of the beatitudes as variations on kingdom of heaven (Betz 1995:111-116, 125-126, 129, 132). ${ }^{15}$ But beyond mere equivalence, the variations on the poor in spirit and the kingdom of heaven progress toward additional insight, and the parallel repetitions with variation bestow a metaphorical flavor on all of the categories of blessedness. That is, they are what Tannehill called "focal-instances" that evoke considerations far beyond their immediate meaning (Tannehill 1975:53, 67-77; Kennedy 1984:51). Further,

\footnotetext{
${ }^{14}$ W Davies and D Allison $(1988: 436-439,451)$ suggest that Mt 5:4 alludes to Is 61 , including the inheritance of the land in 61:7, though their emphasis is on the influence of Isaiah in Q (see Guelich 1982:80-83, 100).

${ }^{15}$ Dupont $(1969-73: 1.251-52 ; 3.474,544)$ derives the first and third beatitudes from one alleged Aramaic original. For him, "meek" designates primarily an attitude toward others rather than a social state (3.486-545) (see Guelich 1982:74-75, 81-82; Davies \& Allison 1988:449; Luz 1989:232, 235-36; Strecker 1970-71:264). On the starting point of Jesus' proclamation of the kingdom as the extermination of evil and the restoration of God's power, see Stegemann $(1982: 12,14)$.
} 
the tension born from associating blessedness with the absence of accouterments focuses the blessedness on being rather than having (Reuter 1979:88-90). More to the point, intertextuality endows Mt 5:5 with a metaphorical quality not only in terms of the predicate "meek" but in terms of the figurative interplay of the entire beatitude with Ps 36 LXX and with Abrahamic covenant traditions.

This metaphorical quality should not be confused, however, with "spiritualizing" the social and political realities of what it means to belong to the meek. The mediation of Abrahamic covenant traditions to Matthew through Ps 36 LXX underlines the point. Not only is Ps 36 LXX suffused with Abrahamic tradition motifs (inheritance of the land occurs at least six times in vv 9, 11, 18, $22,29,34)$. The wicked also stand over against those to whom the land is promised in two ways. First, because the opponents prosper by unjust behavior, one could be tempted to adopt their behavior in order to prosper like them (vv 1, 7,38 ). Second, the wicked oppress those who are identified as meek in $v 11$ by violence. They watch closely for an opportunity, apparently to take advantage of those who live by fair play ( $v 12$ ). They engage in economic abuse by borrowing and failing to repay ( $v 21$ ). They use weapons to oppress violently and even to kill the poor and needy $(v 14,32)$. Moreover, the psalm's repeated promise to the poor that they will inherit land indicates that the wicked deprive them of ownership and access to land - the perennial problem of the poor and oppressed (see Carter 2000:132-133) as it is today in Latin America, Zimbabwe, and South

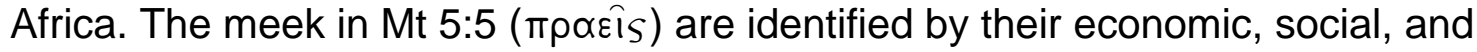
political position as much as they are by their relationship to Jesus who shows concretely what it is to be meek $(11: 29,21: 5)$. Further, Walter Wink has shown that such economic, social, and political issues are reflected elsewhere in the context, especially in Jesus' advice about turning the other cheek, giving up one's cloak to a litigant as well as one's coat, and going the second mile (5:39-42) (Wink 1992:185-193).

But it is Abrahamic covenant traditions that are mediated to Matthew through Ps 36 LXX. I attempt to identify some of the intertextual interplay with the 
caveat that these identifications do not exhaust the interplay. Indeed, the reciprocal play back and forth of intertextual figuration cannot be exhausted. (1) The intertextual relationship is ironic in that there are two levels of understanding. One is the inheritance of the land of Canaan as a fulfillment of the Abrahamic promise. This is the level of understanding in Ps 36:11 LXX. The meek are contrasted with the sinner (o $\alpha \mu \alpha \rho \tau \omega \lambda o^{\prime}, \mathrm{v} 10$ ), and the psalm constantly reiterates the two ways between the wicked and those who depend upon God. It thus affirms the continuing inheritance through the distribution of the land of Canaan after the conquest in keeping with the Abrahamic covenant (Weiser 1962:316-323). But Matthew suppresses the possession of Canaan and pushes the inheritance of the earth to a second level far beyond the inheritance of Canaan. (2) This second level of understanding is also hyperbole, that is, when the successor text revisits the inheritance of the land, it rises, like an eye watching a revolving barber's pole, to a higher level. (3) The successor text also participates in metonymy, because as heirs of the earth, the meek are associated with the offspring of Abraham. (4) The intertextual interplay is simultaneously metaleptic. When Jewish tradition pushed the inheritance of the land beyond Canaan, it created a trope on the conquest. The beatitude, therefore, is a figuration on what is already figurative - metalepsis.

Moreover, the beatitude involves abductive reasoning. ${ }^{16}$ Ps $36: 11$ LXX is a straightforward assertion: "The meek shall inherit land." In contrast, the basis for the blessedness of the meek in the second clause of Matthew's beatitude gives it a syllogistic-like form. As is usually the case with abductive reasoning, some of the assertions are unexpressed, and readers must supply them. Further, though the assertions of abductive rhetoric may be cultural assumptions that would not qualify as premises in a formal syllogism, they are valid for persuading everyone who shares the assumptions. In its intertextual interplay, Mt 5:5 makes assertions following the abductive pattern rule + result = case. Rule: The descendants of Abraham will inherit the earth. Result: The meek will inherit the earth. Case: The

\footnotetext{
${ }^{16}$ Kennedy (1984:16, 49-51) correctly identifies the syllogistic-like character of the beatitudes but erroneously categorizes them as deductive.
} 
meek are descendants of Abraham. The beatitude expresses an abductive association between the case and the rule. Thus, the meek belong to the class of the descendants of Abraham. The case also expresses an association with the result that it anticipates: They will inherit the earth. Betz characterizes the "logic" of blessedness as God's justice (Betz 1995:119, 124). The intertextual interplay, however, makes it also a matter of identifying the meek as children of Abraham who are heirs of God's promise.

David Hellholm (1998:296-304, 311-312) ${ }^{17}$ describes two basic potential functions for the beatitudes in the sermon on the mount: (1) declarations of consolation with a promise of reversal, in which case conditions such as meekness already exist or (2) ethical exhortations with the promise of reward conditional on fulfilling requirements that do not exist prior to the exhortation. The first is open to hearers to accept the blessing; the second establishes a requirement for the hearers to accept in order to receive the blessing. Mark Allen Powell (1996) astutely suggests that the first four beatitudes promise divine reversal for the oppressed and the last four demand ethical action on behalf of the oppressed in the first four. According to Hellhom's categories, the first four essentially mean "blessed are you when you are oppressed." The second four exhort disciples to act on behalf of the oppressed. Powell (1996:460-479) describes the oppressed in direct universal terms apart from any identification with Israel or with Jesus' disciples. ${ }^{18}$ I suggest first, however, that the specifications of Jesus' hearers in 4:23-5:1 presupposes an address to Israelites (see 10:5; 15:24) (see Lohfink 1988:18-24, 26-35, 107-109, 199-202; Grundmann 1968:111-115; Frankemölle

\footnotetext{
${ }^{17}$ I have reduced Hellholm's discussion of options to the only two that are applicable in this case (see Guelich 1982:65, 111; Luz 1989:229, 238, 243). But announcing a blessing is performative language that confers the blessing (see Patte 1987:67; Schweizer 1975:81). Daniel Patte (1996) establishes four distinct legitimate readings that he largely attributes to pre-understanding.

${ }^{18}$ Davies and Allison (1988:1.439-40, 466) emphasize the performative blessing over a secondary ethical quality. For H Falcke (1984:380), the beatitudes address humans in their fundamental situation of need and in their capacity as agents of action (see Guelich 1982:89; Allison 1999:41-44). Matthew's formulation in the third person implies universality more than the address in the second person in Luke. Strecker (1970-71:262-266, 271) argues, however, for understanding the first four beatitudes also as ethical prescriptions. Kennedy (1984:51) takes all of the beatitudes as ethical, that is, as deliberative rhetoric. Did 3.7 is imperative and clearly

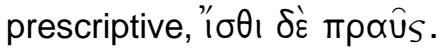


199:200-204, 214). ${ }^{19}$ Universality comes nevertheless indirectly through God's promise that in Abraham all the peoples of the earth would be blessed. In moving to the universal level, the beatitude associates the meek through an abduction with the heirs of Abraham and thus identifies them figuratively with Israel. ${ }^{20}$

Betz (1995:109-110, 118, 130-131, 137-138, 141) takes the third beatitude as a development on "poor in spirit" (5:3) and argues that the context in 5:17-48; 6:25-34; and 7:24-27 compels hearers to understand it as prescribing an ethical stance of becoming aware of the human conditions of poverty or remaining aware of the same with the promise of an eschatological reward (cf Hellholm 1998:324). Betz, however, interprets the sermon on the mount on the level of a tradition that pre-dates its incorporation into Matthew so that its context is the sermon on the mount itself and not the larger context of Matthew.

By contrast, I wish to place the third beatitude in its Matthean context. First, it appears within an inclusio for the entire book that identifies Jesus as "God is with us" $(1: 23 ; 28: 20)$. The sermon on the mount is thus the proclamation of the one in whom God is present. ${ }^{21}$ Second, Mt 4:17 is programmatic: "From then on Jesus began to preach and to say, 'Repent. The kingdom of heaven is at hand."' As Jack Kingsbury (1986:4, 13, 57-77) has shown, this narrator's proleptic summary influences the narrative until 16:20 (cf Allison 1999:xi, 9; Luz 1989:215, 235; Guelich 1982:56). ${ }^{22}$ Further, a summary of Jesus' proclamation of the kingdom and his beneficent acts in synagogues introduces the sermon on the mount (4:23-25) (Davies 1966:100, 435). The beatitudes, therefore, describe the way things are, as Powell (1996:465) aptly paraphrases, when "heaven rules

\footnotetext{
${ }^{19}$ Against restricting Jesus' ministry to Israel, see W D Davies (1966:326-333).

${ }^{20}$ Allison (1999:47-49) overlooks the Abrahamic promise and suggests echoes of Adam and Eve and Moses (see Lohfink 1988:38).

${ }^{21}$ Davies (1966: 430-435) affirms Jesus' messianic consciousness (see Stanton 2001:52).

Reciprocally, the beatitudes characterize who Jesus is (Davies \& Allison 1988:1.466; see Allison 1999:9, 15).

${ }^{22}$ Ulrich Luz takes Mt 4:17 as an indication that the kingdom is still in the future. Patte $(1987: 66)$ supports a kingdom with both present and future dimensions.
} 
them.. ${ }^{23}$ By discarding all literary contexts, Hellholm (1998:334-440) argues for understanding the beatitudes on the level of the historical Jesus as present over against an eschatological future. ${ }^{24}$ But according to 4:17-25 Jesus' preaching initiates God's rule that is breaking in at the edge where God's future is becoming the present also in the Matthean context. Jesus' announcement is performative and confers blessing in the present even if the reversal that is the basis for blessedness lies still in the future. "In connection with the proclamation of Jesus the things about which he spoke came to pass" (Stegemann 1982:17). ${ }^{25}$

In the case of Mt 5:5 Jesus asserts that the meek belongs to the class "children of Abraham" who are the recipients of the promise that they will inherit the earth. The class "children of Abraham" and the promise are already known. What is new is that the meek belong to the children of Abraham. This intertextual abduction may prod readers to a new construct of reality. First, it disorients by an element of disappointment, that is, the meek are blessed rather than the powerful. But then it disorients by anticipation. They will inherit the earth. The new construct is grounded in something ancient, the Abrahamic covenant tradition. But this ancient Abrahamic covenant tradition is revisioned in terms of the kingdom of God and its proclaimer.

\footnotetext{
${ }^{23}$ According to Lapide (1982:33), the "beatitudes are ... the joyful message that one can believe that God the Father ... is capable of a reversal of all earthly values." Kennedy (1984:43, 48-49, 53-54) takes Mt 5:3-13 as a proem that introduces the heart of the theme of the sermon on the mount, Jesus as fulfillment of the law in 5:17-20. For me, 4:17 indicates that the kingdom is thematic.

${ }^{24}$ Betz (1995:119) states that the eschatological concept that God's kingdom is to come in the future does not preclude its reality in the present (see Luz 1989:231; Schweizer 1975:81, 90).

${ }^{25}$ According to Dupont (1969-73:1.111) the "[kingdom] is so near that already its effects are felt" (see Weder 1985:56-57; Guelich 1982:78, 81, 85, 88, 99, 111). On the future nuance of the dependent clauses formulated in the future see Strecker (1970-71:261, 263, 271). But there is also for Strecker (1970-71:274) a present claim of blessedness. So also Davies and Allison (1988:1.389-92, 446; see Stanton 2001:52). The sermon on the mount "looks backwards, from the consummation to the present" (Allison 1999:12).
} 


\section{Works consulted}

Allison, D C 1999. The Sermon on the Mount: Inspiring the moral imagination. NewYork: Crossroad.

Bateson, G \& Bateson, M 1987. Angels fear: Towards an epistemology of the sacred. New York: Macmillan.

Betz, H 1995. The Sermon on the Mount: A commentary on the Sermon on the Mount, including the Sermon on the Plain. Minneapolis: Fortress. (Hermeneia.)

Black, C 2001. The rhetoric of the gospel: Theological artistry in the Gospels and Acts. St Louis: Chalice.

Bloom, H 1973. The anxiety of influence: A theory of poetry. New York: Oxford University Press.

Bloom, H 1975. Kabbalah and criticism. New York: Seabury.

Bloom, H 1982. The breaking of the vessels. Chicago: University of Chicago Press.

Boyarin, D 1990. Intertextuality and the reading of Midrash. Bloomington: Indiana University Press.

Brawley, R 1995. Text to text pours forth speech: Voices of Scripture in Luke-Acts. Bloomington: Indiana University Press.

Brodie, T 2000. The crucial bridge: The Elijah-Elisha narrative as an interpretive synthesis of Genesis-Kings and a literary model for the gospels. Collegeville, MN: Liturgical Press.

Brodie, T 1992. Fish, temple, tithe, and remission: The God-based generosity of Deuteronomy 14-15 as one component of Matt 17:22-18:35. RB 99, 697-718.

Broer,I 1986. Die Seligpreisungen der Bergpredicht: Studien zu ihrer Überlieferung. Bonn: Peter Hanstein.

Carter, W 2000. Matthew and the margins: A sociopolitical and religious reading. Maryknoll, NY: Orbis.

Culler, J 1981. The pursuit of signs. Ithaca: Cornell University Press.

Davies, W D 1966. The setting of the Sermon on the Mount. Cambridge: Cambridge University Press.

Davies, W D \& Allison, D C 1988. A critical and exegetical commentary on the Gospel according to Saint Matthew, Vol 1. Edinburgh: Clark.

Dupont, J 1969-73. Les béatitudes. Tomes 1-3. Paris: Gabalda.

Falcke, H 1984. Die Seligpreisungen der Bergpredict und das gesellschaftliche Zeugnis der Kirche. ZEE 28.

Fann, K 1970. Peirce's theory of abduction. The Hague: Martinus Nijhoff.

Finkelpearl, E 2001. Pagan traditions of intertextuality in the Roman world, in MacDonald, D (ed), Mimesis and intertextuality in antiquity and Christianity. Harrisburg, PA: Trinity Press International.

Fitzmyer, J 1960-61. The use of explicit Old Testament quotations in Qumran literature and in the New Testament. NTS 7, 305-330. 
Frankemölle, H 1971. Die Makarismen (Mt 5,1-12; Lk 6,20-23): Motive und Umfang der redaktionellen Komposition. BZ 15.

Frankemölle, H 1994. Matthäus Kommentar, 1. Düsseldorf: Patmos

Guelich, R 1982. The Semon on the Mount: A foundation for understanding. Waco, TX: Word.

Gundry, R 1967. The use of the Old Testament in St Matthew's gospel with special reference to the Messianic hope. Leiden: Brill.

Grundmann, W 1968. Das Evangelium nach Matthäus. Berlin: Evangelische Verlagasanstalt. (THNT 1.)

Hellholm, D 1995. Enthymemic argumentation in Paul: The case of Romans 6, in Engberg-Pedersen, T (ed), Paul in his Hellenistic context. Minneapolis, MN: Fortress.

Hellholm, D 1998. Beatitudes and their illocutionary functions, in Collins, A (ed), Ancient and modern perspectives on the Bible and culture: Essays in honor of Hans Dieter Betz. Atlanta, GA: Scholars Press.

Kennedy, G 1984. New Testament interpretation through rhetorical criticism. Chapel Hill: University of North Carolina Press.

Kingsbury, J D 1986. Matthew as story. Philadelphia: Fortress.

Kristeva, J 1980. Desire in language: A semiotic approach to literature and art. New York: Columbia University Press.

Lanigan, R 1995. From enthymeme to abduction: The classical law of logic and the postmodern rule of rhetoric, in Langsdorf, L \& Smith, A (eds), Recovering pragmatism's voice: The classical tradition, Rorty, and the philosophy of communication. Albany: SUNY Press.

Lapide, P 1982. Die Bergpredigt - Utopie oder Programm?. Mainz: Matthias-Grünewald.

Lohfink, G 1988. Wem gilt die Bergpredigt? Beiträge zu einer christlichen Ethik. Freiburg: Herder.

Luz, U 1989. Matthew 1-7: A commentary. Minneapolis, MN: Augsburg.

Mead, R 1963-64. A dissenting opinion about respect for context in Old Testament quotations. NTS 10, 279-289.

Menken, M 2000. The quotation from Jeremiah 31 (38).15 in Matthew 2.18: A study of Matthew's scriptural text, in Moyise, S (ed), The Old Testament in the New Testament: Essays in honour of J L North. Sheffield: Sheffield Academic Press.

Ochs, P 1998. Peirce, pragmatism and the logic of scripture. Cambridge: Cambridge University Press.

Patte, D 1987. The Gospel according to Matthew: A structural commentary on Matthew's faith. Philadelphia, PA: Fortress.

Patte, D 1996. Discipleship according to the Sermon on the Mount: Four legitimate readings, four plausible views of discipleship, and their relative values. Valley Forge, PA: Trinity Press International. 
Peirce, C 1957. The logic of abduction, in Essays in the philosophy of science. New York: The Liberal Arts Press.

Powell, M A 1996. Matthew's beatitudes: Reversals and rewards of the Kingdom. CBQ 58.

Powery, E 1999. Jesus reads Scripture: The function of Jesus' use of Scripture in the Synoptic Gospels. PhD dissertation, Duke University.

Reilly, F 1970. Charles Peirce's theory of scientific method. New York: Fordham University Press.

Rese, M 1969. Alttestamentiliche Motive in der Christologie des Lukas. Gütersloh: Mohn. Reuter, H-R 1979. Die Bergpredigt als Orientierung unseres Menschseins heute. ZEE 23.

Schweizer, E 1975. The Good News according to Matthew. Atlanta: John Knox.

Senior, D 1997. The lure of the formula quotations: Re-assessing Matthew's use of the Old Testament with the passion narrative as a test case, in Tuckett, C (ed), Scripture in the Gospels, 89-115. Leuven: Leuven University Press. (BETL 131.)

Smith D M 1972. The use of the Old Testament in the New, in Efrid, J (ed), The use of the Old Testament in the New and others essays: Studies in honor of $W$ Stinespring. Durham, NC: Duke University Press.

Stanton, G 2001. What is the law of Christ? Ex Auditu 17.

Stegemann, H 1982. Der lehrende Jesus. NZSTh 24.

Strecker, G 1970-71. Die Makarismen der Bergpredigt. NTS 17.

Tannehill, R 1975. The sword of his mouth. Phialdelphia, PA: Fortress.

Weder, H 1985. Beobachtungen zum Verständnis der Bergpredigt Jesu. ET 45. Weiser, A 1962. The Psalms: A commentary. Philadelphia, PA: Westminster. (OTL.)

Wink, W 1992. Engaging the powers: Discernment and resistance in a world of domination. Minneapolis: Fortress. 